\title{
CORRIGENDUM
}

\section{Genome-wide inbreeding estimation within Lebanese communities using SNP arrays}

Nadine Jalkh, Mourad Sahbatou, Eliane Chouery, André Megarbane, Anne-Louise Leutenegger and Jean-Louis Serre

\section{ERRATUM}

\section{The phenotype of congenital insensitivity to pain due to the Nav1.9 variant p.L811P}

Christopher Geoffrey Woods, Mohamed Osman Eltahir Babiker, Iain Horrocks, John Tolmie and Ingo Kurth

European Journal of Human Genetics (2015) 23, 1434; doi:10.1038/ejhg.2015.163

Correction to: European Journal of Human Genetics (2015) 23, 561-563; doi:10.1038/ejhg.2014.166; published online 13 August 2014

Unfortunately the affiliation of CG Woods was shown incorrectly as: Institute of Human Genetics, Jena University Hospital, Jena,
Germany. His correct affiliation is: Department of Medical Genetics, Cambridge Institute for Medical Research, Addenbrooke's Hospital, Cambridge, UK.

The typesetters would like to apologise for their error. 